\title{
DNA damage response in prostate cancer cells by proton microbeam irradiation
}

\author{
Xue Chen ${ }^{1,2}$, Qi Yu ${ }^{1,2}$, Xufei Wang ${ }^{3}$, Ping Li $^{4}$, Qing Zhang ${ }^{4}$, Shen Fu ${ }^{1,2,3,5}$ \\ ${ }^{1}$ Department of Radiation Oncology, Fudan University Shanghai Cancer Center, Shanghai, China; ${ }^{2}$ Department of Oncology, Shanghai Medical \\ College, ${ }^{3}$ Key Laboratory of Nuclear Physics and Ion-beam Application (MOE), Fudan University, Shanghai, China; ${ }^{4}$ Department of Radiation \\ Oncology, Shanghai Proton and Heavy Ion Center, Shanghai, China; ${ }^{5}$ Department of Radiation Oncology, Shanghai Concord Cancer Hospital, \\ Shanghai, China \\ Contributions: (I) Conception and design: X Chen, S Fu; (II) Administrative support: Q Zhang, S Fu; (III) Provision of study materials or patients: X \\ Chen, X Wang; (IV) Collection and assembly of data: X Chen; (V) Data analysis and interpretation: X Chen, Q Yu, P Li; (VI) Manuscript writing: All \\ authors; (VII) Final approval of manuscript: All authors. \\ Correspondence to: Shen Fu. 270 Dong An Road, Xuhui District, Shanghai 200032, China. Email: shen_fu@hotmail.com.
}

Background: In cancer radiotherapy, microbeam is an advanced and effective tool in investigating radiobiology. Currently, evidence to support the radiobiology of proton beam radiotherapy for prostate cancer is limited. This study aimed to investigate the DNA damage response of proton microbeam irradiation in prostate cancer.

Methods: Single-particle irradiation system to cells (SPICE) was used to perform the proton microbeam radiation-induced DNA damage response. The SPICE can deliver defined number of protons $(3.4 \mathrm{MeV})$ to the cell nucleus. Different quantities of protons were irradiated to observe differential dose responses in prostate cancer cells. A total of 500 protons or defined proton doses were applied to PC-3 cell nucleus to investigate the kinetics of DNA double-strand breaks (DSB) repair after different time intervals; between 1 and $24 \mathrm{~h}$ post-irradiation. Subsequently, immunofluorescent staining of $\gamma-\mathrm{H} 2 \mathrm{AX}$ was performed to detect DSB, and images were captured by immunofluorescence microscopy. Finally, $\gamma$-H2AX fluorescence intensity in each nucleus was quantified with Image J software.

Results: Proton microbeam radiation-induced DSB were dependent on proton dose applied. After irradiated with 500 protons, relative expression levels of $\gamma-\mathrm{H} 2 \mathrm{AX}$ were time dependent during DSB repair process. The $\gamma$-H2AX fluorescence intensity was maximum at $1 \mathrm{~h}$ post-irradiation. However, a gradual decrease was observed from 4 to $24 \mathrm{~h}$.

Conclusions: Microbeam is a valuable tool for the exploration of DSB response. The findings of the present study show that microbeam irradiation targeted the nucleus with precision. This study is the first to reveal that immune-stained $\gamma-\mathrm{H} 2 \mathrm{AX}$ assay with proton microbeam irradiation could predict DSB repair kinetics in PC-3 cells.

Keywords: DNA damage response; irradiation; microbeam irradiation; proton radiotherapy; prostate cancer

Submitted Dec 22, 2019. Accepted for publication Jun 23, 2020.

doi: $10.21037 /$ tcr-19-2915

View this article at: http://dx.doi.org/10.21037/tcr-19-2915

\section{Introduction}

Radiotherapy is one of the main treatment options for localized prostate cancer $(1,2)$. Radiotherapy, specifically proton radiotherapy, has the advantage of high-dose deposition and precise tumor target thus less adverse effects $(3,4)$. Therefore, many prostate cancer patients in American, Europe, and Asia opt to receive proton radiotherapy (5-7).

Proton radiotherapy is considered the most advanced 
technology in radiation field (8). Currently, to improve the precision of proton beam radiotherapy, pencil-beam scanning irradiation with a small beam can be applied in the clinic. However, information about radiobiology of proton radiotherapy is scanty. With an increasing demand for proton radiotherapy, it is necessary to find the right tool to study the radiobiology of proton radiotherapy. We found microbeam is valuable tool in the study of radiobiology. Microbeam is a beam with micrometer or sub-micrometer diameter and has been extensively applied in the exploration of radiation-induced biological responses at sub-cellular targets (9-11). For example, studies have reported the average diameter of the cell nucleus to be $5-10 \mu \mathrm{m}$, and the proton microbeam is about $2 \mu \mathrm{m}(12,13)$. To investigate cellular radiobiological effects, microbeam can be applied to selectively irradiate individual cells within a cell population (14). Therefore, microbeam irradiates with high spatial accuracy to the cell nucleus. Currently, few studies have focused on radiobiology of proton microbeam $(15,16)$, especially in prostate cancer (17). Therefore, this study was conducted to investigate DNA damage response to proton microbeam in prostate cancer.

Radiation-induced cell killing usually involves targeting the cell nucleus and causing DNA double-strand breaks (DSB). The phosphorylated member of the $\mathrm{H} 2 \mathrm{~A}$ protein family, $\gamma-\mathrm{H} 2 \mathrm{AX}$, is a biomarker of DSB. It is useful in the detection of DNA damage and repair (18). Previous studies have indicated that $\gamma-\mathrm{H} 2 \mathrm{AX}$ can predict the efficacy of cancer therapy treatments, especially some forms of chemotherapy and radiotherapy that induce DNA damage (19). Therefore, $\gamma-\mathrm{H} 2 \mathrm{AX}$ induced to detect proton microbeam irradiation-induced DSB in this research. In this study, proton microbeam was performed to irradiate prostate cancer cells with a defined number of protons at various time intervals. Proton microbeam delivered doses precisely to the cell nucleus, which induced DSB in selected cell populations.

\section{Methods}

\section{Cell culture}

Prostate cancer PC-3 cells were provided by Cell Bank, Chinese Academy of Sciences. The F12K medium mixed with $10 \%$ fetal bovine serum (Gibco, Grand Island, NY, USA) was used for cell culture. The cells were cultured at $37^{\circ} \mathrm{C}$ in a humidified atmosphere with $5 \% \mathrm{CO}_{2}$ to maintain physiological $\mathrm{pH}$.

\section{Sample preparation and microbeam irradiation}

This was performed according to the method described in literature with few modifications $(13,20)$. Briefly, cells were plated on a dish that was specifically designed for proton microbeam irradiation. A special $6 \mu \mathrm{m}$ polypropylene film (Chemplex Industries, FL, USA) was attached to the dish (diameter, $24 \mathrm{~mm}$ ). To make sure that the cells were attached to the dish, $1 \mathrm{~mL}$ of $100 \mathrm{ng} / \mathrm{mL}$ fibronectin solutions (Wako, Chemical Industries, Osaka, Japan) was added to the film and incubated for $2 \mathrm{~h}$, then rinsed with phosphate-buffered saline (PBS) twice before seeding cells. A total of $5 \times 10^{4}$ PC- 3 cells in $1 \mathrm{~mL}$ medium were seeded two days before irradiation.

The irradiation was performed by proton microbeam system, Single-Particle Irradiation System to Cells (SPICE) at the National Institute of Radiological Sciences (NIRS) in Japan. The SPICE is a focused vertical microbeam system composed of a tandem accelerator and operation system (13). The PC-3 cells were irradiated by proton microbeam (3.4 MeV, LET $11.7 \mathrm{keV} / \mu \mathrm{m}$ ) with a beam diameter of $2 \mu \mathrm{m}$. Instructions on irradiation procedures were obtained from literature (13). The SPICE dish was covered with mylar film before irradiation to protect against desiccation. With the advantage of microbeam, only the cell nucleus was irradiated using the online SPICE system. To verify the dose-response of proton microbeam in prostate cancer cells, 100, 250, 500 protons were delivered to the target area of X-Y coordinates, and the results were observed $1 \mathrm{~h}$ post-irradiation. To verify whether DNA damage response was dependent on duration of exposure, 500 protons were delivered to the cells and to observe the results after $1,4,8$, $24 \mathrm{~h}$ irradiation.

\section{Immunofluorescence staining for $\gamma-\mathrm{H} 2 \mathrm{AX}$}

To detect DSB, $\gamma$-H2AX was used as a representative biomarker. Cells for the dose-response experiment were prepared for $\gamma-\mathrm{H} 2 \mathrm{AX}$ staining $1 \mathrm{~h}$ post-proton microbeam irradiation, whereas those for time-dependent experiments were prepared for the same staining after defined time of irradiation. To begin the staining process, the medium was moved, and the cells were washed thrice with cold PBS. Cells were then fixed with $4 \%$ paraformaldehyde at room temperature for $10 \mathrm{~min}$. After fixation, $1 \mathrm{~mL}$ blocking solution containing $1 \%$ bovine serum albumin (BSA), $5 \%$ goat serum, and $0.1 \%$ Tween 20 (Wako, Chemical Industries, Osaka, Japan) in PBS was added to the cells 
then incubated for $1 \mathrm{~h}$ at $37^{\circ} \mathrm{C}$. Subsequently, the blocking solution was removed, and the dish was rinsed twice with PBS, after which $300 \mu \mathrm{L}$ of primary antibody, anti- $\gamma-\mathrm{H} 2 \mathrm{AX}$ [anti-Phospho-Histone H2A.X (ser 139) Antibody, clone JBW301, Merk Millipore, Germany] was added to the dish and incubated at $37^{\circ} \mathrm{C}$ for $1 \mathrm{~h}$. The antibody was diluted to 1:500 with antibody buffer $(0.1 \%$ BSA, $0.3 \%$ Triton X-100 in PBS) [Wako, Chemical Industries, Osaka, Japan] before use. The dish was washed twice with PBS buffer to remove the antibody. The secondary antibody was diluted to 1:1,000 in antibody buffer (goat anti-Mouse IgG, Alexa Fluor 555, Thermo Fisher Scientific, Waltham, MA, USA) and $300 \mu \mathrm{L}$ of the antibody solution was added to the SPICE dish then incubated at $37^{\circ} \mathrm{C}$ for $1 \mathrm{~h}$. The solution was removed by washing the dish twice with PBS, then $1 \mathrm{~mL}$ of Hoechst 33342 (1:2,000 dilution, DOJINDO, Japan) was added to the SPICE dish followed by incubation at $37^{\circ} \mathrm{C}$ for 30 minutes. Finally, to remove the Hoechst solution, the dish was washed twice with PBS then $2 \mathrm{~mL}$ of PBS was added to the dish before irradiation. The images were captured with offline SPICE system.

\section{Quantification of fluorescence intensity}

Detection and quantification of $\gamma-\mathrm{H} 2 \mathrm{AX}$ were performed on immune-stained cells using a fluorescent microscope, offline SPICE system. The microscope was equipped with 40x water immersion objective lens (LUMPLFLN-W $40 \times$ W, NA: 0.8, Olympus, Japan) and a C-MOS camera; the light source was provided by a mercury lamp $(130 \mathrm{~W}$, U-HGLGPS, Olympus, Japan). The detail of this microscope is described elsewhere (13). To capture the images, the filter was changed for various fluorescence; for example, the filter for Hoechst 33342 was U-MNUA2. The same procedure was used to capture images of the control group. After adjusting the parameters to focus on the target area, all images were automatically captured using the microscope.

To analyze these images, Image J software (21) was used to quantify fluorescence. The cell nucleus was stained with Hoechst 33342, whereas $\gamma$-H2AX was stained with Alexa Fluor 555. All the images were imported as a tile into Image $\mathrm{J}$ software from an image sequence menu. Cell nuclei were distinguished from the background according to threshold button, and the corresponding information including area, size and mean fluorescence intensity per pixel were obtained from the region of interest (ROI). These ROIs applied to
Alexa Fluor 555 images, which indicated the fluorescence intensity of $\gamma-\mathrm{H} 2 \mathrm{AX}$. And the intensity measurements per cell nucleus were presented as average of each category of cells. The mean fluorescence intensity of $\gamma-\mathrm{H} 2 \mathrm{AX}$ for each duration of exposure was normalized against the nonirradiated control group.

\section{Statistical analysis}

All data from this study are represented as the mean \pm standard deviation. The values are averages of three independent experiments. To compare means of two different groups, Student's $t$-test was performed at significance level of $\mathrm{P}<0.05$. We used SPSS version 23.0 software for statistical analysis.

\section{Results}

\section{Precision irradiation with proton microbeam}

In this study, we investigated the DNA damage response of prostate cancer cells with microbeam irradiation. Because the beam diameter was about $2 \mu \mathrm{m}$, it was possible to target the cell nucleus or the cell cytoplasm with precision (Figure 1A). However, the accuracy of broad-beam irradiation was not the same as microbeam; thus, some doses scattered near the nucleus (Figure 1A). Figure $1 B$ shows the target area of the cell nucleus by microbeam with $\mathrm{X}-\mathrm{Y}$ coordinates. And Figure $1 C$ demonstrates the representation of $\gamma$-H2AX expression at the DSB site by microbeam and broad-beam in PC-3 cells. The bright field or foci shows stained $\gamma$-H2AX antibody, which highlights the effect of DSB. Microbeam radiation-induced DNA damage was focused on the cell nucleus, and all the dose deposition targeted the nucleus. On the contrary, broadbeam radiation-induced dose distribution was scattered.

\section{Induction of $\gamma-H 2 A X$ in $\mathrm{PC}-3$ cells with dose response}

To investigate the function of proton microbeam in prostate cancer, dose variation response was evaluated. The experiments were conducted with 0 (control group), 100, 250 , and 500 protons to irradiate PC-3 cells. The results demonstrated that $\gamma-\mathrm{H} 2 \mathrm{AX}$ expression level rose with increased irradiation (Figure $2 A$ ). This was highly significant $\left({ }^{*}, \mathrm{P}<0.05 ;{ }^{* *}, \mathrm{P}<0.01\right.$; $\left.{ }^{* *}, \mathrm{P}<0.001\right)$ compared to the control group. 

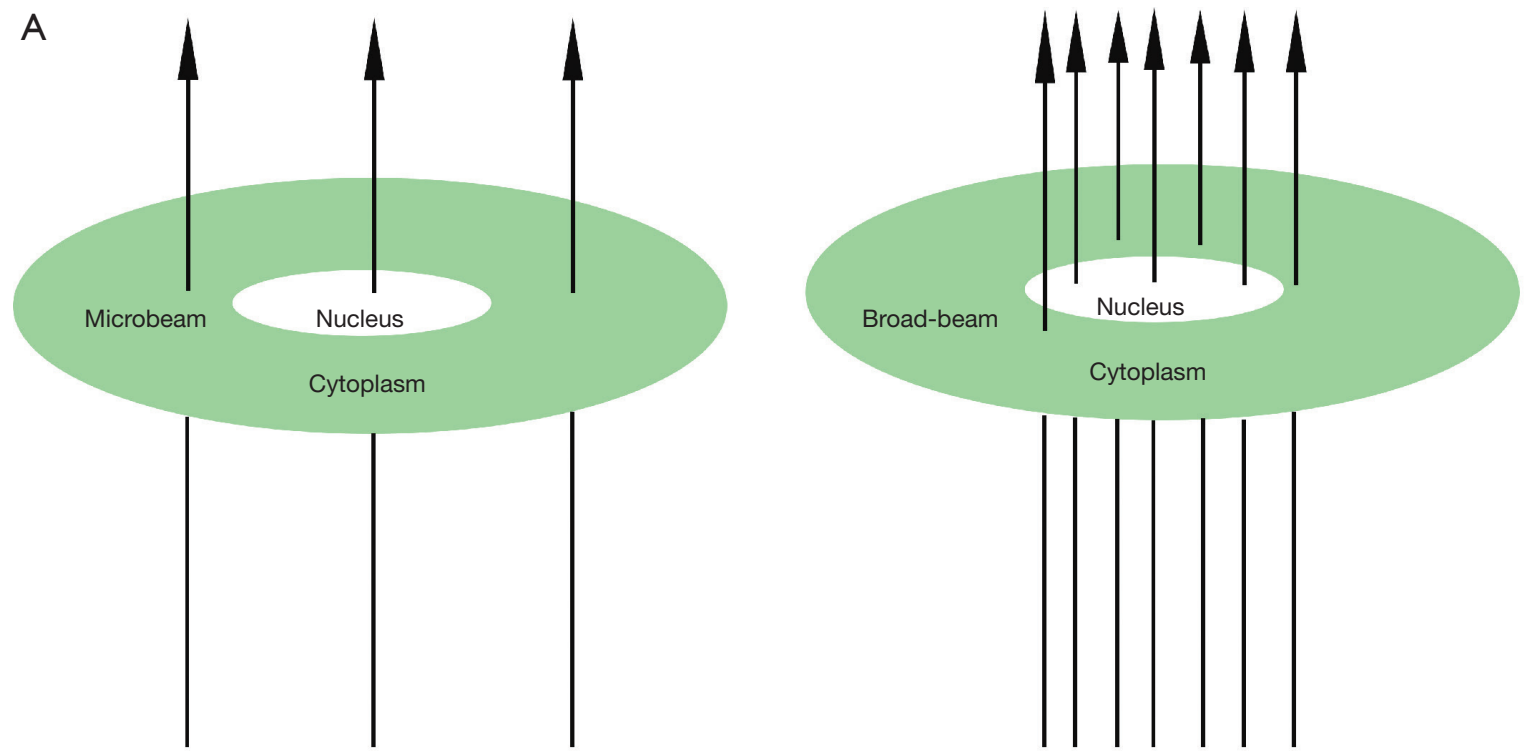

B

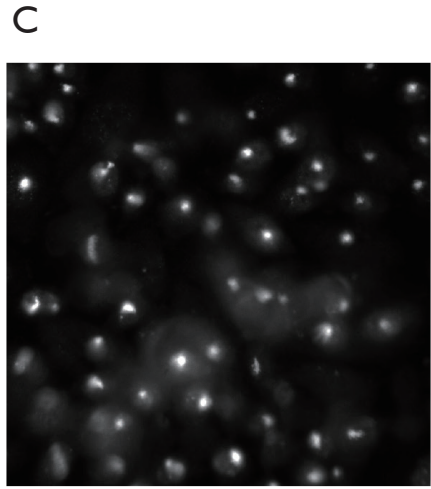

Microbeam

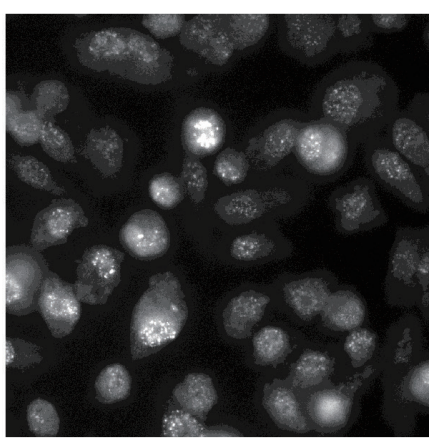

Broad-beam

Figure 1 The model of microbeam and broad-beam irradiation. (A) Proton microbeam targeted the cell nucleus or cytoplasm precisely, whereas broad-beam radiation lacked precision, and got scattered in cells; (B) schematic representation of SPICE-dish target areas by microbeam irradiation with X-Y coordinates; (C) representative image of $\gamma$-H2AX fluorescence with microbeam and broad-beam irradiation $(40 \times) ; \gamma$-H2AX foci collected only at the irradiation site with microbeam irradiation; but broad-beam induced $\gamma$-H2AX expression scattered near the nucleus. The contrast of the photos was enhanced by software, but the other parameters remained the same. SPICE, single-particle irradiation system to cells.

\section{Induction of $\gamma-H 2 A X$ after different times of exposure}

The expression level of $\gamma$-H2AX increased after $1 \mathrm{~h}$ of proton microbeam irradiation. However, after 4 , 8 , and $24 \mathrm{~h}$ of irradiation, the $\gamma-\mathrm{H} 2 \mathrm{AX}$ level decreased because of the repair process (Figure $2 B$ ). The $\gamma-\mathrm{H} 2 \mathrm{AX}$ level was higher than in the control group at $24 \mathrm{~h}$ post-irradiation. These results indicated that the cells could have recovered gradually from DSB, and the $\gamma-\mathrm{H} 2 \mathrm{AX}$ expression level was time-dependent. The representative image of $\gamma$-H2AX expression level with microbeam irradiation was provided
(Figure 3). Also, the $\gamma$-H2AX expression level was showed after irradiated by different number of proton (Figure 4).

\section{Discussion}

Prostate cancer has been the main cause of morbidity among men in the United States in the past decade. A total of 174,650 estimated new cases were reported in 2019, and this was the highest among other cancer cases (22). The prostate cancer incidence rate is sixth in China and is increasing steadily (23). To arrest the progression of prostate 
A

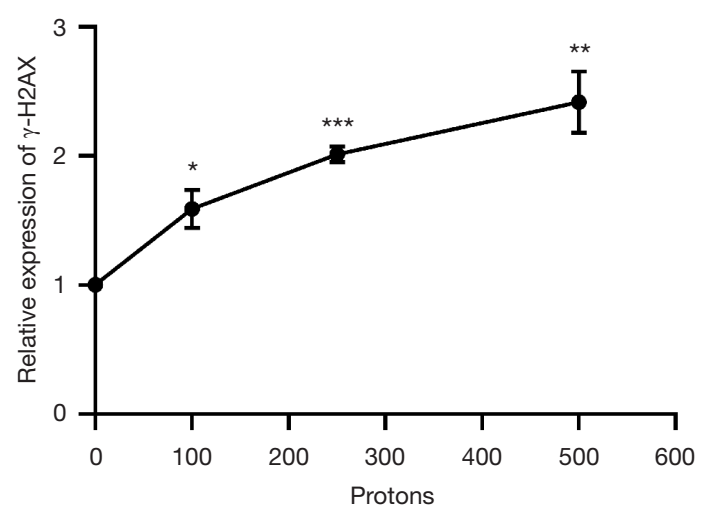

B

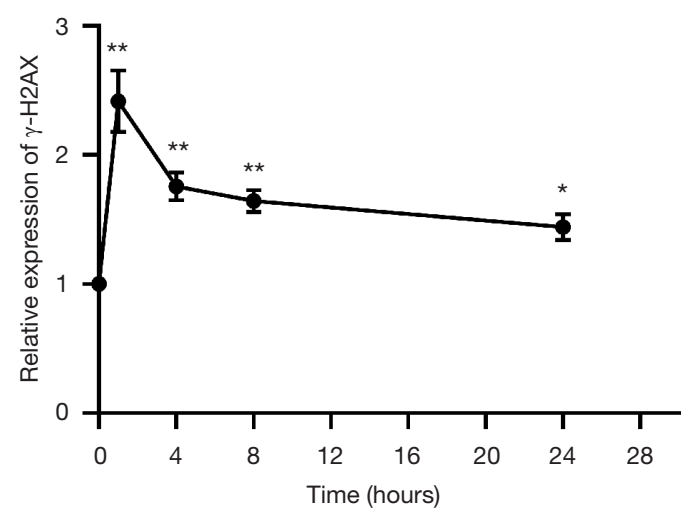

Figure 2 Dose and time responses of $\gamma-\mathrm{H} 2 \mathrm{AX}$ expression levels after irradiation. (A) Response of $\gamma$-H2AX expression levels after proton microbeam irradiation of different doses; (B) response of $\gamma$-H2AX expression levels after proton microbeam irradiation at different exposure durations. Significance levels of *, $\mathrm{P}<0.05 ;{ }^{* *}, \mathrm{P}<0.01$; ${ }^{* * *}, \mathrm{P}<0.001$ compared to control group. All data were normalized to control.

cancer, radiotherapy is recommended as the standard treatment for localized prostate cancer. Accumulating evidence from clinical trials demonstrates that proton beam radiotherapy not only targets tumors precisely but also spare the surrounding normal tissues from unintended damage. Proton beam radiotherapy has salient features that aid in killing tumors, thus improving the quality of life. Many outstanding results have been achieved against many cancers by application of proton radiotherapy, including prostate cancer. However, the mechanism of radiobiology in proton beam therapy is still unclear. What's more, the appropriate tool for studying proton therapy radiobiology is unidentified.

To investigate the radiobiological effect of the proton beam irradiation, we found microbeam was a valuable and effective tool. Microbeam was used to target cellular compartment (the cell nucleus) in selected cell populations. The main aim was to investigate the association between proton microbeam and DNA damage response and repair. Increasing evidence indicates that $\gamma-\mathrm{H} 2 \mathrm{AX}$ is highly expressed during DNA damage response and DSB repair. Rogakou et al. and his colleagues reported that $\mathrm{H} 2 \mathrm{AX}$ is phosphorylated at serine 139 , and $\gamma-\mathrm{H} 2 \mathrm{AX}$ is rapidly recruited to DNA lesion within seconds following DSB induced by ionizing radiation. Based on their findings, they concluded that $\gamma-\mathrm{H} 2 \mathrm{AX}$ formation is sensitive to DNA damage and rapidly responds to DNA double-strand breaks (18). The DNA damage response transfer signals to phosphorylation of $\mathrm{H} 2 \mathrm{AX}$ to $\gamma-\mathrm{H} 2 \mathrm{AX}$.

To investigate proton microbeam radiation-induced response, a dose-escalation experiment was performed with a defined number of protons. The immune-stained $\gamma-\mathrm{H} 2 \mathrm{AX}$ expression levels increased $1 \mathrm{~h}$ post-irradiation (Figure $2 A$ ). The current results indicated that proton microbeam induced DNA damage in PC-3 cells was dependent on the amount of proton dose applied. The $\gamma-\mathrm{H} 2 \mathrm{AX}$ fluorescence assay is a sensitive and precise indicator of DSB, $\gamma-\mathrm{H} 2 \mathrm{AX}$ are recruited immediately to the irradiation site after proton microbeam induced DNA damage. Paull et al. reported that DNA repair factors BRCA1, Rad50, Rad51 colocalize with $\gamma-\mathrm{H} 2 \mathrm{AX}$ after DNA damage by irradiation; their DNA repair-deficient cells model suggested that $\gamma-\mathrm{H} 2 \mathrm{AX}$ formation play a vital role in DNA repair (24). Similar findings have indicated that repair protein XRCC1 and 53BP1 colocalize with $\gamma-\mathrm{H} 2 \mathrm{AX}$ at the targeted site, which was useful in monitoring DNA damage at early stages (25). These results reveal that $\gamma-\mathrm{H} 2 \mathrm{AX}$ could have a role in the repair process, which is consistent with this study. In the present study, the change in expression levels of $\gamma-\mathrm{H} 2 \mathrm{AX}$ as a result of irradiation at different time intervals was further investigated to help in understanding the repair process. Results indicated that $\gamma-\mathrm{H} 2 \mathrm{AX}$ expression level reached a maximum value at $1 \mathrm{~h}$ post-irradiation (Figure $2 \mathrm{~B}$ ). And then decreased at $4 \mathrm{~h}$ post-irradiation. This could mean that the DNA repair kinetic was faster than damage response. A further decrease in $\gamma-\mathrm{H} 2 \mathrm{AX}$ expression level was observed from 4 to $24 \mathrm{~h}$ post-irradiation. The gradual appearance and disappearance of $\gamma$-H2AX foci suggested that the DNA repair pathway was already activated. These findings demonstrate that microbeam irradiation is capable 


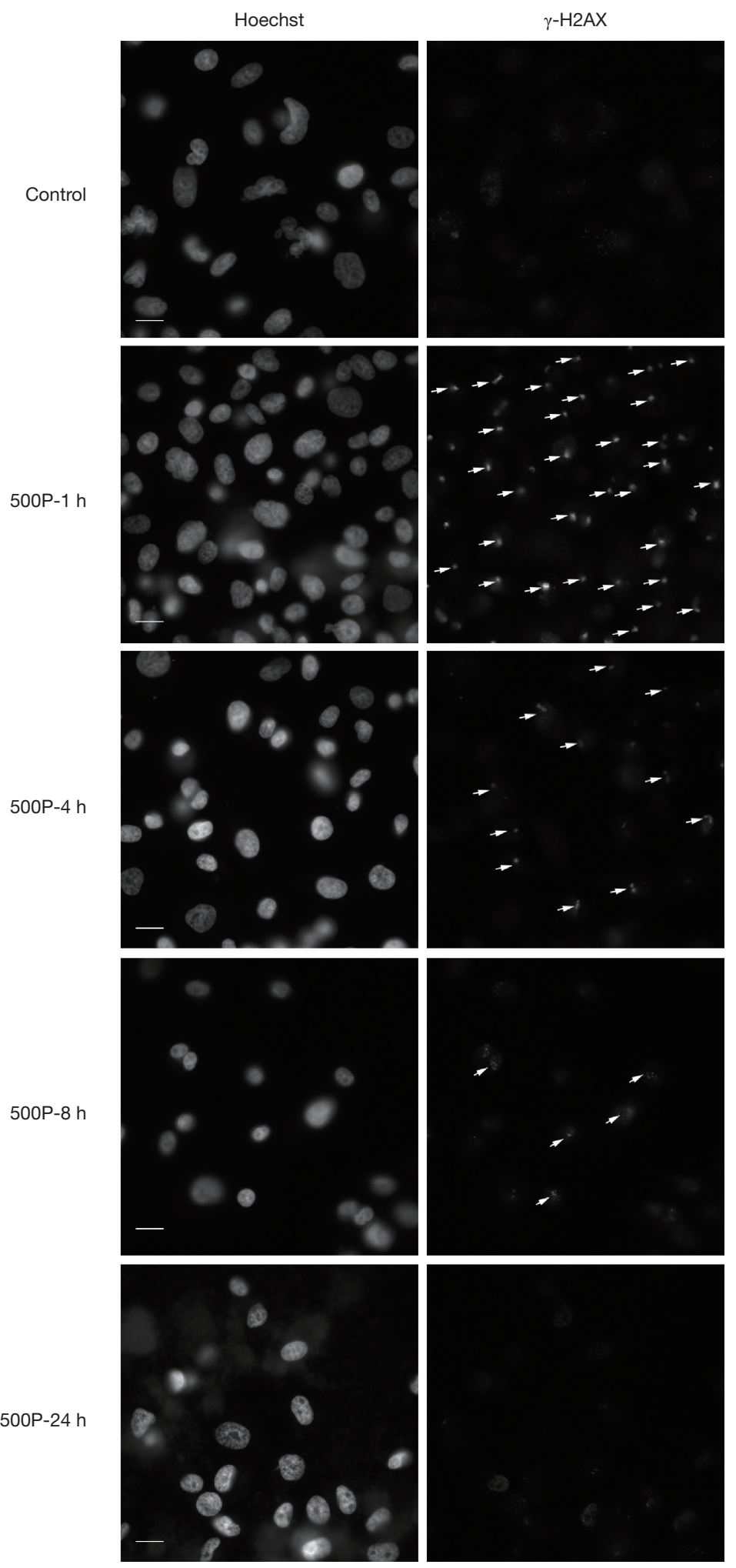

Figure 3 Representative image of $\gamma$-H2AX expression level after irradiated by proton microbeam at different time intervals. The bright-field illumination indicates DSB. The white arrow sign indicates $\gamma$-H2AX foci. The left photos were stained by Hoechst 33342 , and the right-side photos were stained by $\gamma-\mathrm{H} 2 \mathrm{AX}$ antibodies. Scale bar: $20 \mu \mathrm{m}$. DSB, DNA double-strand breaks. 

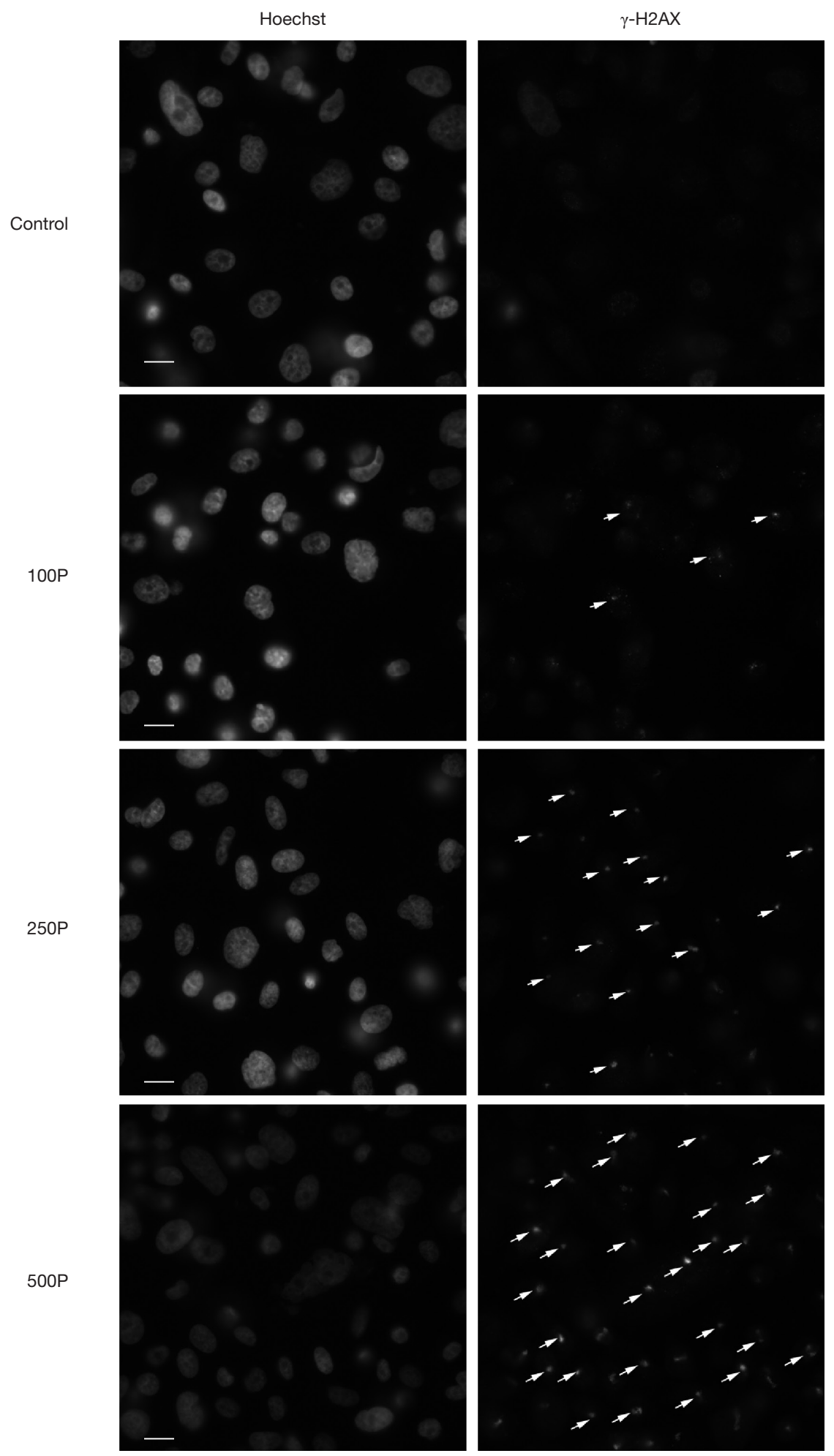

Figure 4 Representative image of $\gamma-\mathrm{H} 2 \mathrm{AX}$ expression level after irradiated by different number of protons. Cells were irradiated with 100 , 250 and 500 protons. The bright-field illumination indicates DSB. The white arrow sign indicates $\gamma$-H2AX foci. The left photos were stained by Hoechst 33342, and the right-side photos were stained by $\gamma$-H2AX antibodies. Scale bar: $20 \mu \mathrm{m}$. DSB, DNA double-strand breaks. 
of inducing DSB and activated repair pathway.

In the present study, microbeam irradiation induced cell death precisely. More time is needed to repair DSB in cases where most of the irradiation doses met their target. Microbeam irradiation deposited all the proton doses into the cell nucleus. During the DNA repair process, $\gamma-\mathrm{H} 2 \mathrm{AX}$ fluorescence intensity gradually disappeared. The kinetics of DNA repair process showed different radiosensitivity. In general, proton microbeam irradiation was precise and efficient in targeting tumor cells and could be useful in investigating radiobiology. The biomarker $(\gamma-\mathrm{H} 2 \mathrm{AX})$ was sensitive in predicting DSB and DNA repair process in prostate cancer after proton microbeam irradiation.

Many previous studies have revealed two main DNA repair pathways, that is, homologous recombination (HR) and non-homologous end-joining (NHEJ) (26,27). However, DNA repair mechanisms are still unclear. Many factors could trigger the DNA damage response and repair. Signaling pathways including bystander effect, adaptive response, and genomic instability affect DNA response to irradiation $(26,28)$. Therefore, in this study, we focus on verifying whether microbeam irradiation could monitor DSB and DNA repair via $\gamma-\mathrm{H} 2 \mathrm{AX}$ expression. The details of DNA damage response and repair mechanisms are beyond the scope of this study.

Despite the many advantages of using a proton microbeam model to estimate the DNA damage and repair process in prostate cancer cells, this study has some limitations. Two main DNA repair pathways have not been discussed in detail. Thus, further studies are needed to explain these processes further. This study focused more on the association of $\gamma-\mathrm{H} 2 \mathrm{AX}$ with proton microbeam induced DSB response and DNA repair. This was the first step in the investigation of proton microbeam radiobiological response with $\gamma-\mathrm{H} 2 \mathrm{AX}$. However, multiple cell lines should be considered in future studies on the same.

\section{Conclusions}

In summary, microbeam is a valuable and effective tool to investigate radiobiology. The results showed that proton microbeam irradiation is more capable of precisely delivering doses to the cell nucleus. The phenomenon of appearance and disappearance of $\gamma-\mathrm{H} 2 \mathrm{AX}$ fluorescence was sensitive to proton microbeam irradiation-induced DNA damage response. Microbeam radiation-induced DSB response and repair was dose and time-dependent and was based on $\gamma-\mathrm{H} 2 \mathrm{AX}$ fluorescence intensity.

\section{Acknowledgments}

We highly thank Professor Teruaki Konishi and his team members (Dr. Yoshiya Furusawa, Dr. Alisa Kobayashi, Dr. Daisuke Ohsawa) at the National Institute of Radiological Science (NIRS) for their technical help and excellent support.

Funding: This work was supported by the National Key Research and Development Program of China (No. 2017YFC0107600), the National Natural Science Foundation of China (No. 81773225).

\section{Footnote}

Data Sharing Statement: Available at http://dx.doi. org/10.21037/tcr-19-2915

Conflicts of Interest: All authors have completed the ICMJE uniform disclosure form (available at http://dx.doi. org/10.21037/tcr-19-2915). The authors have no conflicts of interest to declare.

Ethical Statement: The authors are accountable for all aspects of the work in ensuring that questions related to the accuracy or integrity of any part of the work are appropriately investigated and resolved.

Open Access Statement: This is an Open Access article distributed in accordance with the Creative Commons Attribution-NonCommercial-NoDerivs 4.0 International License (CC BY-NC-ND 4.0), which permits the noncommercial replication and distribution of the article with the strict proviso that no changes or edits are made and the original work is properly cited (including links to both the formal publication through the relevant DOI and the license). See: https://creativecommons.org/licenses/by-nc-nd/4.0/.

\section{References}

1. Martin NE, D'Amico AV. Progress and controversies: Radiation therapy for prostate cancer. CA Cancer J Clin 2014;64:389-407.

2. Zietman AL, Bae K, Slater JD, et al. Randomized trial comparing conventional-dose with high-dose conformal radiation therapy in early-stage adenocarcinoma of the prostate: long-term results from proton radiation oncology group/american college of radiology 95-09. J Clin Oncol 2010;28:1106-11. 
3. Sidaway P. Proton therapy delays progression. Nat Rev Urol 2016;13:181.

4. Mohan R, Grosshans D. Proton therapy - Present and future. Adv Drug Deliv Rev 2017;109:26-44.

5. The LO. Proton therapy for prostate cancer: time for evidence. Lancet Oncol 2014;15:775.

6. Iwata $H$, Ishikawa $H$, Takagi $M$, et al. Long-term outcomes of proton therapy for prostate cancer in Japan: a multi-institutional survey of the Japanese Radiation Oncology Study Group. Cancer Med 2018;7:677-89.

7. Royce TJ, Efstathiou JA. Proton therapy for prostate cancer: A review of the rationale, evidence, and current state. Urol Oncol 2019;37:628-36.

8. Terasawa T, Dvorak T, Ip S, et al. Systematic review: charged-particle radiation therapy for cancer. Ann Intern Med 2009;151:556-65.

9. Wu J, Hei TK. Focus small to find big - the microbeam story. Int J Radiat Biol 2018;94:782-8.

10. Heiss M, Fischer BE, Jakob B, et al. Targeted irradiation of Mammalian cells using a heavy-ion microprobe. Radiat Res 2006;165:231-9.

11. Hable V, Greubel C, Bergmaier A, et al. The live cell irradiation and observation setup at SNAKE. Nucl Instrum Methods Phys Res B 2009;267:2090-7.

12. Prise KM, Schettino G, Folkard M, et al. New insights on cell death from radiation exposure. Lancet Oncol 2005;6:520-8.

13. Konishi T, Oikawa M, Suya N, et al. SPICE-NIRS Microbeam: a focused vertical system for proton irradiation of a single cell for radiobiological research. J Radiat Res 2013;54:736-47.

14. Ghita M, Fernandez-Palomo C, Fukunaga H, et al. Microbeam evolution: from single cell irradiation to preclinical studies. Int J Radiat Biol 2018;94:708-18.

15. Kobayashi A, Tengku Ahmad TAF, Autsavapromporn $\mathrm{N}$, et al. Enhanced DNA double-strand break repair of microbeam targeted A549 lung carcinoma cells by adjacent WI38 normal lung fibroblast cells via bi-directional signaling. Mutat Res 2017;803-805:1-8.

16. Autsavapromporn N, Liu C, Kobayashi A, et al. Emerging Role of Secondary Bystander Effects Induced by Fractionated Proton Microbeam Radiation. Radiat Res
2019;191:211.

17. Lipiec EW, Wiecheć A, Dulińska-Litewka J, et al. Changes in cellular response to the damage induced in PC-3 prostate cancer cells by proton microbeam irradiation. Gen Physiol Biophys 2012;31:11.

18. Rogakou EP, Pilch DR, Orr AH, et al. DNA doublestranded breaks induce histone $\mathrm{H} 2 \mathrm{AX}$ phosphorylation on serine 139. J Biol Chem 1998;273:5858-68.

19. Ivashkevich A, Redon CE, Nakamura AJ, et al. Use of the $\gamma$-H2AX assay to monitor DNA damage and repair in translational cancer research. Cancer Lett 2012;327:123-33.

20. Kobayashi A, Autsavapromporn N, Ahmad TAFT, et al. Bystander WI-38 cells modulate DNA double-strand break repair in microbeam-targeted A549 cells through gap junction intercellular communication. Radiat Prot Dosimetry 2019;183:142-6.

21. Rasband WS, ImageJ, U. S. National Institutes of Health, Bethesda, Maryland, USA. Available online: https://imagej. nih.gov/ij/, 1997-2018.

22. Siegel RL, Miller KD, Jemal A. Cancer statistics, 2019. CA: A Cancer Journal for Clinicians 2019;69:7-34.

23. Chen $W$, Zheng R, Baade PD, et al. Cancer statistics in China, 2015. CA Cancer J Clin 2016;66:115-32.

24. Paull TT, Rogakou EP, Yamazaki V, et al. A critical role for histone $\mathrm{H} 2 \mathrm{AX}$ in recruitment of repair factors to nuclear foci after DNA damage. Curr Biol 2000;10:886-95.

25. Jakob B, Splinter J, Conrad S, et al. DNA double-strand breaks in heterochromatin elicit fast repair protein recruitment, histone $\mathrm{H} 2 \mathrm{AX}$ phosphorylation and relocation to euchromatin. Nucleic Acids Res 2011;39:6489-99.

26. Clouaire T, Rocher V, Lashgari A, et al. Comprehensive Mapping of Histone Modifications at DNA Double-Strand Breaks Deciphers Repair Pathway Chromatin Signatures. Mol Cell 2018;72:250-262.e6.

27. Mateo J, Boysen G, Barbieri CE, et al. DNA Repair in Prostate Cancer: Biology and Clinical Implications. Eur Urol 2017;71:417-25.

28. van Oorschot B, Uitterhoeve L, Oomen I, et al. Prostate Cancer Patients with Late Radiation Toxicity Exhibit Reduced Expression of Genes Involved in DNA DoubleStrand Break Repair and Homologous Recombination. Cancer Res 2017;77:1485-91.
Cite this article as: Chen $\mathrm{X}, \mathrm{Yu} \mathrm{Q}$, Wang $\mathrm{X}, \mathrm{Li} \mathrm{P}$, Zhang Q, Fu S. DNA damage response in prostate cancer cells by proton microbeam irradiation. Transl Cancer Res 2020;9(8):4811-4819. doi: $10.21037 /$ tcr-19-2915 